Theories \& Applications, the International Edition

Printed Version: (ISSN 2090-5262)

Online Version: (ISSN 2090-5270)

November 2012, Volume 2, No. 3 Pages (65 - 73)

\title{
Time Management in Judo
}

Sherif Mohamed Hanohoum*

\section{Introduction:}

$\mathrm{I}_{\mathrm{n}}^{\mathrm{n}}$ $\mathrm{n}$ light of the present century can be said that time, and not the machine, is the key to progress. That's because it's no longer about the ability of production and the development of equipment and investment of resources as far as speed and skills in doing so, it became time and invest, and administer one of the key elements that govern the quality in each areas. (6:3)

The time of the environmental variables, which are not foreign to any authority the ability to control. There is no provision can delay or time or even increase it or decrease, and the time will come on top of items, or where the evaluation indicators linking the success or failure in achieving the goals set for the schedule to the extent that. (4:170)

In spite of the importance of time in the life of each one of us, but it is noticeable that some people do not realize is estimated the value of time, time is life, time and value and appreciation and good management means making a nation. The United and civilizations are not built and take their place in a vacuum, and the maintenance does not stand only when Alsud them with weapons and gear, but the estimated value of the minute, and second, we are in the world of grappling and accelerates a lot of technological developments that may have given the importance of time and may have deprived the other time value. (3:59)

\section{Research problem:}

Judo is a sport that depends on the management of the time factor, which takes 5 minutes of actual play, whether for men or women, but may extend the time of the match to extra time

*Assistant Professor, Sports Management Department, Faculty of Physical Education for Boys, Helwan University, Egypt. so-called golden time (Gold Score) and runs for 3 more minutes after the end of the original time of the match. (7)

That is, it may extend the time of the match in some cases to 8 minutes and work to good use this time helps to win games, but supports many of the trainers of the highest levels to be exploited efficiently to achieve their goal of winning, especially in games with character and influential level, convergent, with the guidance of coach of the player and their ability to exploit the time is a key factor in winning.

That is due to the work of a researcher in the field of training and inadvertent contact with many coaches and players from different generations and exposure. For many situations faced by both of them work in the training and ex-official, as well as different generations and schools training and therefore different opinions. Here we find the research problem in the management of the time in judo matches and one of the important methods that are effective in the management of the effectiveness of games

\section{The importance of research:}

The importance of time is in its stability. Time will remain on this earth constant does not change, o'clock will remain the time and today is the day and month is the month and can not be changed and will not number more than the conventional. Regardless of the method used to measure, it is not possible for any human being on earth to change or affect the time, but it is possible to manage the same for the time. $(2: 13)$

Man works accomplished during the time each of them (human and time) could not be retrieved or replaced. This requires that you take advantage of the individual every moment in his life do not waste time, or includes the best use 
of time to take advantage of human resources, finance and management within this time and so efficiently and effectively. (8:49)

Have been raised in the recent past in various media in the victory of player national team of Judo in the weight under $100 \mathrm{~kg}$ on his Israeli opponent in one of Grand Slam tournaments, Germany, and when you watch this match and analysis we find that it did not end for any of technical points, but ended by warnings and use the time well

It was an impressive match to qualify for the Olympics and get the third place and bronze medal in the tournament. Although of this fight is the second time, which is facing the Egyptian player the Israeli player after their facing each other about 6 months before in a Grand Slam tournament in Moscow, which ended in wining for Israeli player in this game despite the progress Egyptian player, but that the difference between the two fights was the management process time during the match, which is exploited by the coach and player in the second fight between the two high efficiency to achieve good result to win the match.

Highlights of the importance of research in the following points:

- Lack of studies on time management games in Judo as it is of great importance in winning games next aspects of physical and skill.

- There are many aspects to be considered during the setup process for the players, including the time factor which is of great importance in the tactical training.

- Find the side contributes to other studies in the Arab Republic of Egypt to provide solutions to the problems in a scientific manner legalized sports.

\section{Objective of this research:}

- Identify the method of time management games in judo.

- Study the differences in the style of time management games in Judo, according to the experience.

\section{Find the imposition:}

- There are differences in the management of the time in judo matches according to the experience.

\section{Search Terms:}

\section{Judo:}

Offensive and defensive means upscale require great skill with its own rules and scientific assets using different arts to achieve the efficiency of the mind and body. (5:14)

\section{Time management:}

Is the process by which the distribution of time effectively in order to show the various tasks completed in a timely and specific with high efficiency. (9:15)

\section{Previous studies:}

Marwa Mahmoud Ezzat Abdel-Latif (10) in 2003 to study entitled "Evaluation of time management to coaches swimming during the training season." The researcher used the descriptive method and included a sample of the study for 210 trainer than 20 club sports are a community of research and study aimed to assess the management of time to swim instructors during the training season and was the most important results of this study:

- Swimming coaches not to take advantage of the element of time.

- Lack of clarity of the goals of swimming coaches

Yehya Fikry (12) in 2002 to study entitled "Measuring the efficiency of time management and the realities of managers in youth centers," The study aimed to design a measure of the efficiency of time management and to identify the competence of managers through the development of goals and identify the tasks and priorities and meet the necessities The researcher used the descriptive method and use questionnaire as a tool for data collection and study population included the youth centers. The most important results of the study:

- Director of the youth center is planned to be implemented in a specified period and without decided what to do. 
- Director of the youth center does not result in anything of the work planned and dispersal of activity occurs.

Ahmed Mahmoud Abdel-Dayem (1) In 2002 a study titled "Assessment of time management in some team sports Olympics" and the researcher used the descriptive method and the questionnaire and analysis of documents as tools for data collection and study aims to evaluate time management in some team sports Olympic and included a sample search on the group of administrators in team sports federations and Olympic was the most important results of this study:

- That the time factor of the important factors set by the unions within the elements of the Department.

- Organization is an important and vital role in the investment of time and managed properly.

- Identification of the target makes it there in the development and effective implementation of the plan, which helps in the investment of time.

\section{Foreign studies:}

Petters \& Rutte (15) in 2005 to study entitled "The administration's conduct of the time on average to the requirements of work." The study sample included 123 teachers at the elementary level. The researchers assume that there is interaction between time management and work requirements and burnout. Researchers have pointed out that the interaction between high work demands and poor ability to manage time may predict psychological burn people with low-grade teachers in the management of time. Has upheld the imposition the study for Lostnzaf emotional, which was more dimensions to predict the combustion psychological teachers. Hypothesis also upheld in part after the completion of the profile.
By Jeong (14) in 2000 to study entitled "burnout, time management." The study sample included Americans working in several vocational centers. Researcher used measure of psychological Maslash of combustion. The study aimed to study the time in the light of the age and experience. The results of the study include:

- the presence of a moderate relationship between burnout and behaviors of time management.

- There is significant difference on the scale of time management between subjects who attended the seminars on time management and Subjects who did not attend these workshops.

The Briddle (13) in 1996 to study entitled " Time Management and the pattern of behavior"A". Ostmat sample of 50 managers from managers of the university. In order to study the effectiveness of a training program for time management to ease the pressures of professional and modify the pattern of behavior "A" and the researcher followed the experimental method has been used to measure researcher pattern of behavior "A" and another to measure the pressures of work. The results of the study:

- the effectiveness of the training program in reducing stress and modifying professional behavior pattern "A" to the subjects, leading to improved time management for them.

\section{Research procedures:}

\section{Sample:}

The research sample included a number (32) for player of the national team's first judo and who spent at least 3 years in the ranks of teams of national and international experiences to them .Was selected in the manner deliberate.

Table (1)

The community sample

\begin{tabular}{|c|c|c|c|c|}
\hline Sample & Age & Belt degree & \multicolumn{2}{|c|}{ Experience } \\
\hline $\begin{array}{c}\text { National team players 1 } \\
\text { row }\end{array}$ & Over 18 years old & Black belt & Few & Large \\
\cline { 3 - 5 } & & $\begin{array}{c}\text { From 3:5 } \\
\text { years }\end{array}$ & $\begin{array}{c}\text { Over 5 } \\
\text { years }\end{array}$ \\
\hline
\end{tabular}




\section{Approach:}

The researcher used survey method to identify the method of time management the subject of study

\section{Tools:}

- The official records to account for the number of players and know their results

- Interview

- Questionnaire through the design of a questionnaire prepared by the researcher was followed by:

- The stage of expert opinion in the questionnaire was taken into account in the experts to be available to have one of these conditions:

- Have a Ph.D. in the field of tests and measurements

- He holds a PhD is sports management.

- He holds a PhD is sports training

- To have experience in the field of training of not less than 15 years.

- The experts were asked the following:

- Express an opinion on the appropriateness of expressions for the field of Physical Education.

- Add, remove or edit statements on the subject of study.

- The appropriateness of the formulation of terms of the level of understanding.

\section{Exploratory experiment:}

The researcher has made exploratory experience on 10/2/2012 on sample of (10) players of the community sample and the aim of the exploratory experiment follows:

First: find out the suitability of the terms of the level of understanding of where the drafting of players.

Second: Find out any other difficulties facing the player or researcher.

The results of this experiment that, for:

The first objective: suitable statements in terms of wording and level of understanding.

The second objective: the absence of any difficulties or obstacles.

And therefore there is no change any of the phrases in questionnaire (28) phrases.

\section{Transaction account of the scientific scale:}

\section{First: Calculate the factor of sincerity:}

The researcher calculates the internal consistency of the axis and by finding the correlation coefficients between each grade and each phrase axis.

Table (2)

Values of the correlation between the degree of each term and the total degree of the scale

\begin{tabular}{|c|c|c|c|c|c|c|c|}
\hline $\begin{array}{c}\text { The correlation } \\
\text { coefficient }\end{array}$ & $\mathrm{S}$ & $\begin{array}{c}\text { The correlation } \\
\text { coefficient }\end{array}$ & $\mathrm{S}$ & $\begin{array}{c}\text { The } \\
\text { correlation } \\
\text { coefficient }\end{array}$ & $\mathrm{S}$ & $\begin{array}{c}\text { The } \\
\text { correlation } \\
\text { coefficient }\end{array}$ & $\mathrm{S}$ \\
\hline$*, 750$ & 22 & $*, 799$ & 15 & 503, & 8 & $*, 810$ & 1 \\
\hline$*, 812$ & 23 & $*, 866$ & 16 & 110, & 9 & $*, 904$ & 2 \\
\hline$*, 902$ & 24 & $*, 749$ & 17 & $*, 843$ & 10 & $*, 798$ & 3 \\
\hline$*, 853$ & 25 & $*, 811$ & 18 & $*, 768$ & 11 & $*, 888$ & 4 \\
\hline$*, 800$ & 26 & $*, 788$ & 19 & $*, 903$ & 12 & $*, 748$ & 5 \\
\hline$*, 762$ & 27 & $*, 872$ & 20 & $*, 813$ & 13 & $*, 823$ & 6 \\
\hline$*, 751$ & 28 & $*, 786$ & 21 & $*, 753$ & 14 & $*, 911$ & 7 \\
\hline
\end{tabular}

Is clear from Table (2):

There is a statistically significant correlation between the degree of each term and the total degree of the scale, except for (2) is not acceptance. And thus became the standard in its final form (26) is after you delete the phrases (8.9) of the first picture.

\section{Stability coefficient:}

The researcher used Cronbach alpha factor to calculate the stability. 
Table (3)

Cronbach alpha values \& Retail midterm scale

\begin{tabular}{|c|c|}
\hline Statement & Value \\
\hline The correlation coefficient between the two parts &, 7235 \\
\hline Jetman Factor &, 6011 \\
\hline The number of words the first part & 13 phrases \\
\hline The number of words the second part & 13 phrases \\
\hline Alpha factor the first part &, 6423 \\
\hline Alpha factor the second part &, 6591 \\
\hline
\end{tabular}

Is clear from the table (3):

The correlation coefficient between the two parts $(, 7235)$ which is satisfactory to accept the value of the stability of the scale and that the benefit of the application.

\section{The main application:}

Researcher started applying the questionnaire to the members of the research sample, which amounted to (22) players on 17/2/2012 were excluded (4) players which are qualified for the Olympics and already benefiting from the time factor during the games. To become the number of the core sample (18) players.

The researcher follows in the application of the search tool:

Researcher selected training times to display the scale on the players, after obtaining the appointment of coach.

- Exclude the coach while answering on the scale.

Results:
- Explain the objective of this research for the players and the confidentiality of data as well as reference not needing to write name.

- Left to the players freedom of answering without affecting by the researcher or coach where it does not exist for the during the scale displaying.

- Researcher did not restrict players to a time to answer.

- The researcher reviewed the form almost upon receipt to avoid any lack of data.

\section{Statistical treatment:}

Data were treated statistically using SPSS, which includes the following:

First: Spearman correlation coefficient in order to calculate true.

Second: Cronbach's alpha coefficient in order to calculate stability.

Third: Mann Whitney to calculate the sign of the differences.

Table (4)

The arithmetic mean, standard deviation and coefficient of torsion of the sample responses on the scale according to experience

\begin{tabular}{|c|c|c|c|c|c|c|}
\hline \multirow{2}{*}{ The scale } & \multicolumn{3}{|c|}{ Long Exp (7) } & \multicolumn{3}{c|}{ Short Exp (11) } \\
\cline { 2 - 7 } & $\mathrm{Am}$ & $\mathrm{Sd}$ & $\mathrm{Ct}$ & $\mathrm{Am}$ & $\mathrm{Sd}$ & $\mathrm{Ct}$ \\
\hline Time management & 71,00 & 2,30 & $-2,16$ & 41,18 & 3,25 & $-0,348$ \\
\hline
\end{tabular}

Is clear from Table (4):

Value of the arithmetic mean of the players (the long experience) was (71.00) with a standard deviation (2.30), while the value of the arithmetic mean of the players with short experience (41.18) with a standard deviation (3.25), which indicates the ability of players to experience in managing their time during the performance. 
Table (5)

Differences between the two groups (long / short experience) in the measure their response to statements

\begin{tabular}{|c|c|c|c|c|c|c|}
\hline S & Phrases & Groups & $\begin{array}{l}\text { Average } \\
\text { ranks }\end{array}$ & $\begin{array}{l}\text { Total } \\
\text { ranks }\end{array}$ & $\mathrm{U}$ & $\begin{array}{l}\text { Signifi } \\
\text { cance }\end{array}$ \\
\hline 1 & $\begin{array}{l}\text { Is there space for the use of time in the planning } \\
\text { process for the match? }\end{array}$ & $\begin{array}{l}\text { Long } \\
\text { Short }\end{array}$ & $\begin{array}{c}14.57 \\
6.27\end{array}$ & $\begin{array}{c}102,0 \\
69,0\end{array}$ & $* 3.00$ & 0.001 \\
\hline 2 & $\begin{array}{l}\text { Is there during the preparation period for the use of } \\
\text { skills into the time? }\end{array}$ & $\begin{array}{l}\text { Long } \\
\text { Short }\end{array}$ & $\begin{array}{c}15.00 \\
6.00\end{array}$ & $\begin{array}{l}105,0 \\
66,00\end{array}$ & $0.00^{*}$ & $0.00 \mathrm{~s}$ \\
\hline 3 & $\begin{array}{l}\text { Is there during preparation period of physical space } \\
\text { for the use of time? }\end{array}$ & $\begin{array}{l}\text { Long } \\
\text { Short }\end{array}$ & $\begin{array}{c}14.36 \\
6.41\end{array}$ & $\begin{array}{l}100,50 \\
70,50\end{array}$ & $4.50^{*}$ & 0.001 \\
\hline 4 & Is there division of time during the game? & $\begin{array}{l}\text { Long } \\
\text { Short }\end{array}$ & $\begin{array}{c}14.29 \\
6.45\end{array}$ & $\begin{array}{c}100,00 \\
71,00\end{array}$ & $5.00^{*}$ & 0.00 \\
\hline 5 & $\begin{array}{l}\text { Is there a time during the game depends on the skill } \\
\text { side only? }\end{array}$ & $\begin{array}{l}\text { Long } \\
\text { Short }\end{array}$ & $\begin{array}{c}13.00 \\
7.27\end{array}$ & $\begin{array}{l}91,00 \\
80,00\end{array}$ & $14.00 *$ & 0.009 \\
\hline 6 & $\begin{array}{l}\text { Is there a time during the game depends on the } \\
\text { physical side only? }\end{array}$ & $\begin{array}{l}\text { Long } \\
\text { Short }\end{array}$ & $\begin{array}{c}15.00 \\
6.00\end{array}$ & $\begin{array}{c}105,00 \\
66,00\end{array}$ & $0.00 *$ & 0.00 \\
\hline 7 & $\begin{array}{l}\text { Is there a time during the game depends on the } \\
\text { tactical side only? }\end{array}$ & $\begin{array}{l}\text { Long } \\
\text { Short }\end{array}$ & $\begin{array}{c}15.00 \\
6.00\end{array}$ & $\begin{array}{c}105,00 \\
66,00\end{array}$ & $0.00^{*}$ & 0.00 \\
\hline 8 & $\begin{array}{l}\text { Is there a certain time to pay attention to your coach } \\
\text { during the game? }\end{array}$ & $\begin{array}{l}\text { Long } \\
\text { Short }\end{array}$ & $\begin{array}{c}12.50 \\
7.59\end{array}$ & $\begin{array}{l}87,50 \\
83,50\end{array}$ & $17.50^{*}$ & 0.023 \\
\hline 9 & $\begin{array}{l}\text { Do you consider the time factor during the match is } \\
\text { important for you? }\end{array}$ & $\begin{array}{l}\text { Long } \\
\text { Short }\end{array}$ & $\begin{array}{c}12.00 \\
7.91\end{array}$ & $\begin{array}{l}84,00 \\
87,00\end{array}$ & $21.00 *$ & 0.044 \\
\hline 10 & $\begin{array}{c}\text { Can you play the game without attention to the } \\
\text { time? }\end{array}$ & $\begin{array}{l}\text { Long } \\
\text { Short }\end{array}$ & $\begin{array}{c}15.00 \\
6.00\end{array}$ & $\begin{array}{c}105,00 \\
66,00\end{array}$ & $0.00^{*}$ & 0.000 \\
\hline 11 & $\begin{array}{l}\text { Do you ask your coach direct you at a certain time } \\
\text { of the game? }\end{array}$ & $\begin{array}{l}\text { Long } \\
\text { Short }\end{array}$ & $\begin{array}{c}14.93 \\
6.05\end{array}$ & $\begin{array}{c}104,50 \\
66,50\end{array}$ & $0.500 *$ & 0.000 \\
\hline 12 & Do you ask your coach direct you all the game? & $\begin{array}{l}\text { Long } \\
\text { Short }\end{array}$ & $\begin{array}{c}15.00 \\
6.00\end{array}$ & $\begin{array}{c}105,00 \\
66,00\end{array}$ & $0.000 *$ & 0.000 \\
\hline 13 & Do you depend on the time factor in training only? & $\begin{array}{l}\text { Long } \\
\text { Short }\end{array}$ & $\begin{array}{c}14.21 \\
6.50\end{array}$ & $\begin{array}{l}99,50 \\
71,50\end{array}$ & $5.50^{*}$ & 0.000 \\
\hline 14 & $\begin{array}{c}\text { Do you depend on the time factor in official } \\
\text { matches only? }\end{array}$ & $\begin{array}{l}\text { Long } \\
\text { Short }\end{array}$ & $\begin{array}{c}12.14 \\
7.82\end{array}$ & $\begin{array}{l}85,00 \\
86,00\end{array}$ & $20.00^{*}$ & 0.033 \\
\hline 15 & Is the game enough time to carry out your goal? & $\begin{array}{l}\text { Long } \\
\text { Short }\end{array}$ & $\begin{array}{l}9.50 \\
9.50\end{array}$ & $\begin{array}{c}66,50 \\
104,50\end{array}$ & $38.50 *$ & 0.000 \\
\hline 16 & $\begin{array}{l}\text { Do you depend on the time factor in the preliminary } \\
\text { round? }\end{array}$ & $\begin{array}{l}\text { Long } \\
\text { Short }\end{array}$ & $\begin{array}{l}9.50 \\
9.50\end{array}$ & $\begin{array}{c}66,50 \\
104,50\end{array}$ & $38.50 *$ & 0.000 \\
\hline 17 & Is the time important to you in the finals? & $\begin{array}{l}\text { Long } \\
\text { Short }\end{array}$ & $\begin{array}{c}15.00 \\
6.00\end{array}$ & $\begin{array}{c}105,00 \\
66,00\end{array}$ & $0.000 *$ & 0.000 \\
\hline 18 & $\begin{array}{l}\text { Do you depend on the time factor of your vision } \\
\text { through visual during the match? }\end{array}$ & $\begin{array}{l}\text { Long } \\
\text { Short }\end{array}$ & $\begin{array}{c}12.50 \\
7.59\end{array}$ & $\begin{array}{l}87,50 \\
83,50\end{array}$ & $17.50^{*}$ & 0.023 \\
\hline 19 & $\begin{array}{l}\text { Do you depend on the time factor through your } \\
\text { coach only? }\end{array}$ & $\begin{array}{l}\text { Long } \\
\text { Short }\end{array}$ & $\begin{array}{c}15.00 \\
6.00\end{array}$ & $\begin{array}{c}105,00 \\
66,00\end{array}$ & $0.000 *$ & 0.000 \\
\hline 20 & $\begin{array}{c}\text { Do you feel psychological comfortable in the } \\
\text { presence of time in front of you during the game? }\end{array}$ & $\begin{array}{l}\text { Long } \\
\text { Short }\end{array}$ & $\begin{array}{c}15.00 \\
6.00\end{array}$ & $\begin{array}{c}105,00 \\
66,00\end{array}$ & $0.000 *$ & 0.000 \\
\hline 21 & $\begin{array}{l}\text { Do you blame other people in the absence of time } \\
\text { during the game? }\end{array}$ & $\begin{array}{l}\text { Long } \\
\text { Short }\end{array}$ & $\begin{array}{c}14.57 \\
6.27\end{array}$ & $\begin{array}{c}102,00 \\
69,00\end{array}$ & $3.000 *$ & 0.000 \\
\hline 22 & $\begin{array}{l}\text { Do you hesitate to play the game in the absence of } \\
\text { what appears the time in front of you? }\end{array}$ & $\begin{array}{l}\text { Long } \\
\text { Short }\end{array}$ & $\begin{array}{c}15.00 \\
6.00\end{array}$ & $\begin{array}{c}105,00 \\
66,00\end{array}$ & $0.000 *$ & 0.000 \\
\hline 23 & $\begin{array}{c}\text { Does your plan in the game in the case of a time in } \\
\text { front of you or not? }\end{array}$ & $\begin{array}{l}\text { Long } \\
\text { Short }\end{array}$ & $\begin{array}{c}13.43 \\
7.00\end{array}$ & $\begin{array}{l}94,00 \\
77,00\end{array}$ & $11.00 *$ & 0.001 \\
\hline 24 & Do you arrange your priorities during the game? & $\begin{array}{l}\text { Long } \\
\text { Short }\end{array}$ & $\begin{array}{c}12.57 \\
7.55\end{array}$ & $\begin{array}{l}88,00 \\
83,00\end{array}$ & $17.00 *$ & 0.030 \\
\hline 25 & Can you use the time in the best use of training? & $\begin{array}{l}\text { Long } \\
\text { Short }\end{array}$ & $\begin{array}{c}15.00 \\
6.00\end{array}$ & $\begin{array}{c}105,00 \\
66,00\end{array}$ & $0.000 *$ & 0.000 \\
\hline 26 & $\begin{array}{l}\text { Can you use the time optimal use in official } \\
\text { matches? }\end{array}$ & $\begin{array}{l}\text { Long } \\
\text { Short }\end{array}$ & $\begin{array}{c}14.93 \\
6.05\end{array}$ & $\begin{array}{c}104,50 \\
66,50\end{array}$ & $0.500 *$ & 0.000 \\
\hline
\end{tabular}

Significance of $>0.05$ 
Is clear from Table (5):

There are statistically significant differences between the two groups about their response to expressions of the scale in favor of the group with the most experience.

Table (6)

Differences between the two groups in total score to scale time management

\begin{tabular}{|c|c|c|c|c|c|}
\hline Scale & Groups & Average ranks & Total ranks & $\mathrm{U}$ & Significance \\
\hline $\begin{array}{c}\text { Time } \\
\text { Management }\end{array}$ & $\begin{array}{l}\text { Long } \\
\text { Short }\end{array}$ & $\begin{array}{c}15.00 \\
6.00\end{array}$ & $\begin{array}{c}105.00 \\
66.00\end{array}$ & $* 0.000$ & $* 0.000$ \\
\hline
\end{tabular}

\section{Significance of $>0.05$}

Is clear from the table (6):

There are significant differences between the two groups in the total score for the scale (time management) for the group with the most experience.

\section{Discussion of the results:}

In light of the results reached by the researcher by data analysis statistically, discuss the results and interpretation in order to achieve the objectives of the research:

To identify the management style games Judo. Has indicated phrases 4, 5, 6, 7, 9 and that got the highest score, which referred to the need split time during the games because the time of matches in Judo is 5 minutes, which may extend to 8 minutes in some cases by regulations International Judo Federation. So, this time is divided into three parts linked to all the physical skills, tactical and reliable player often that not most higher the level of the player. There may be some players who depend on the skills at the beginning of games, so that he can win in the first few minutes of the time the game. Also, there are some players who depend on the physical side in the first phase of the long game, and use elements of physical fitness in progress on the opponents' to open gaps during game enables to use his skills to beat the opponents'. There are some players who depend on stress discount by some elements of fitness (endurance, explosive power), and then use their skills after that to beat the opponent. In some cases, the trainer directs the player in a certain time of the game, and during the timeout of the game is the elapsed time between Mattei, which means (stop) and between Hajimih which means (start). There are some players who depend on the tactical side at the beginning of the games then, depend on the skill side thereafter, which refers to the importance of the division of time into the game, and this is consistent with each of the study (Ahmed Abdel Dayem) (1) and (Going) (14) the need for the division of labor and planning.

As it turns out that there are differences between the players with considerable experience and players with less experience in the use of time also for the benefit of players with considerable experience as indicated phrases 1, 9, 10, 13, $14.18,20,23.24,25,26$ and obtained by the highest score and pointed to the importance of using the time in the planning process for the match because there are a lot of players with extensive experience, and levels comparable in both the physical side and side skills they meet in the final rounds of the competition. And be the time element here is important in the optimal use of the ability to control the times critical of these games. Also, use the time during coach at certain times of the game and need to rely on time both in training and during the preparation period, especially tactical setup before and during official matches. As well as the presence of the time during the game clearly than psychological make him feel comfortable during the game. In addition to prioritize and plans during the game to be able to optimize the use of time in official matches as well as in training and this is consistent with the study of both (Marwa Mahmoud Ezzat) (10) and (Yahya Fikri) (12) and (Bridle) (13) of the existence of some qualities that can be exploited optimum utilization of time management.

\section{Conclusions:}

In light of the research, its goal, and based on what has been of procedures, treatments and statistical interpretation of the results to the researcher reached the following conclusions: 
1. There is no single method agreed to manage the time in judo matches.

2. There are significant differences between experienced players and players with great experience and for at least the players with considerable experience in the management of the time in judo matches.

3. Needs experienced players (large, short) to use the element of time in the process of numbers (physical / skill / tactical)

4. Be the best use of the time in judo matches if the availability of good numbers of players (physically/ skill / tactical).

\section{Recommendations:}

1. It's necessary to Participate international matches for the players with considerable experience to gain international experience in the management of time in the games.

2. It's necessary to participate many games for players with less experience to acquire and apply time management in a judo match.

3. Develop a method to manage the time in judo matches within a period of preparation for the players, especially in the tactical preparation.(Fig 1).

Figure (1)

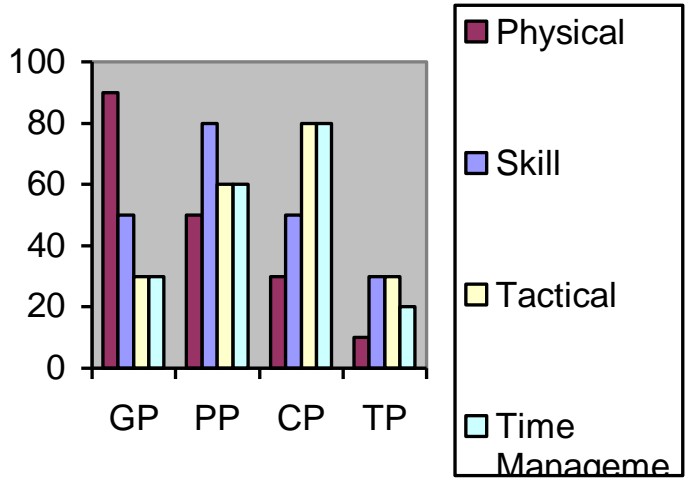

Figure (1) is cleary the importance of using time management during the general preparation (GP), Privet preparation (PP), competition preparation and tactical preparation.

\section{References:}

\section{Arabic References:}

1. Ahmad M Abdel Dayem: "Assessment of time management in some collective Olympic Games", Master Thesis, Faculty of Physical Education, Helwan University, Cairo, 2002.

2. Bassiouni, Mohamed ElBaradei :"My friend the Director and the organization of time," the decision of the Consulting Center, Cairo, 1997.

3. Samira bint Abdullah bin Mustafa Kurdi: "Time management and its relationship to psychological and combustion pattern of behavior among a sample of employees Taif University," Journal of Psychology, numbers (84-87), the 23 year, the Egyptian General Book, 2010.

4. Saleh Nasser Olimat: "Distribution of time to perform the tasks of the professional faculty at the University of Yarmouk," Journal of Educational and Psychological Sciences, Volume III, Issue IV, Faculty of Education, University of Bahrain, 2002.

5. Adel Fawzi Gamal, Sherif M.Hnohoum: "Sports Systems series, judo," the Supreme Council for Youth and Sports, Sector Leadership Development, Cairo, 1992.

6. Ali Ahmed, Moqrb, Mohammed Aladdin: "Department of Arabic language teachers for the time summer high school in the Sultanate of Oman," An Empirical Study, Journal of Research in Education and Psychology, Volume, 11 Issue 4, College of Education, ElMinia University, 1998.

7. The law of Judo: "International Federation of Judo," 2010.

8. Magda Mustapha Abdullah: "Development of the performance of managers of public schools using the entrance time management", Master Thesis, Faculty of Girls, Ain Shams University, 2003. 
9. Hans Marjons: "Time management", Foreign References: translated by Abdullah Bilal, Dar almaarefa of human development, Cairo, 2000

13. Briddle,William,B: The Effects Of Time Management Training Program upon 10. Marwa Mahmoud Ezzat: "Evaluation of time management with swimming coaches during the training season," Master Thesis, unpublished, Cairo, 2003.

11. Nabil Morsy Khalil: Strategic planning, Dar almaarefa algamaya, Alexandria, 1993

12. Yahya Fikry: "Measuring the efficiency of time management and the realities of managers in youth centers, "Master Thesis, unpublished, Cairo,

Occupational stress Levels and the type "A" Behavior Patterns in college Administrators. D.A.I. Vol. 47 No. 12. p. 4245.

14. Jeong, Joseph: A Study Of Burnout and Time Management Among Korean-American Pastors. D.A.I. (A).Vol. No. 11. p.4052.

15. Petters,Miranda.A \& Rutte,Christel.: Time Management, Control Interaction .journal of Occupational Health psychology. Vol .10. No.1.p64-75.

2002. 